\title{
Edwards \& Bell's concept of profit: An empirical analysis on the basis of historical cost and current costing
}

\author{
Golam Mohiuddin \\ Institute of Education, Research \& Training (IERT), University of Chittagong, Bangladesh \\ Email address: \\ gmuddiniert@cu.ac.bd
}

To cite this article:

Golam Mohiuddin. Edwards \& Bell's Concept of Profit: An Empirical Analysis on the Basis of Historical Cost and Current Costing. Journal of Finance and Accounting. Vol. 2, No. 3, 2014, pp. 72-80. doi: 10.11648/j.jfa.20140203.16

\begin{abstract}
The measurement of income occupies a central position in accounting. Income measurement is probably the most important objective and function of accounting, accounting concepts, principles and procedures used by a business enterprise. In general, income represents increase in wealth and success of business; the higher the income, the greater will be the success of a business. The theory of business income as developed by Edgar O. Edwards and Philip W. Bell is a classic treatise. It has attained a reputation as a major contribution to the accounting literature. In the book "The theory and measurement of business income" the authors made to classify the methodological approach in developing the theory of business income, knowledge of how a particular work fits within the array improves our understanding of the evaluation of accounting theory. They have suggested that the central objectives toward which accountants should point in formulating measures of a business income. The general theory of profit maximization by the individual firm provides a simplified picture of the decision-making process under conditions of uncertainty, the process which must be evaluated with the aid of accounting data. They have reconciled economic income and accounting income with considering price level adjustments. An attempt has been taken in this study to clarify these concepts of profit on the basis of historical cost and current costing.
\end{abstract}

Keywords: Profit, Historical Costing, Current Costing, Business Profit, Accounting Profit

\section{Introduction}

Generally, income is the consumption and savings opportunity gained by an entity within a specified timeframe, which is expressed in monetary terms. However, for households and individuals, income is the sum of all the wages, salaries, profits, interest payments, rents and other forms of earnings received in a given period of time. The conventional accounting model based on historical cost was designed for use in a situation where prices are stable or where prices change slowly. The conventional style of accounting does not make any provision for changes in purchasing power. According to conventional theory, the stewardship function of managers must be the focus of attention of accountants in reporting to external parties. Owners and creditors are primarily concerned about what management has done with the funds entrusted to them. Thus the net worth of a firm is not a relevant measure. Stockholders as equity holders wish to know the results of their investment in the corporation. Hence, the determination of income is the most important function for the accountant.
This leads to the view that income statement is the most important financial report since it reveals the results of the operations of the enterprise. Therefore, historical cost is the aggregate price paid by the firm to acquire ownership and use of an asset, including all payments necessary to obtain the asset in the location and condition required for it to provide services in the production or other operations of the firm. Current costs reflect the prices that must be paid for an asset or its use at the date of the balance sheet or the date of the use or sale if that asset is not already owned. Edwards \& Bell (1961) present the first systematic presentation of current cost accounting in 1961 in their classical work, 'The Theory and Measurement of Business Income'. Unlike traditional accounting with the concept of accounting income, Edwards $\&$ Bell introduce the concept of business income. There are two components of business income, namely current operating profit and realizable cost savings. The former is the excess of the current value of the output sold over the current cost of the related inputs. Realizable cost savings are the increase in the current cost of the assets while held by the firm in the current period. In short, holding gains or losses is 
emphasized in current cost accounting. Furthermore, current cost accounting theory recommends that the current cost of assets should be measured and reported in the balance sheet.

\section{Objectives of the Study}

The main objective of the study is to clarify the concept of profit developed by Edgar O. Edwards and Philip W. Bell on the basis of historical cost and current costing system. In order to achieve this main objective the specific objectives are as follows:

(1) to know the concepts of profit developed by Edgar O. Edwards and Philip W. Bell;

(2) to effort on the historical cost and current costing; and

(3) to elucidate the profit concepts on the basis of historical cost and current costing.

\section{Methodology of the Study}

This study is theoretical in nature. It is exclusively based on secondary data. The main sources of the information and data used in this study are relevant books, documents, articles, and web sites. An effort has been made in this study to provide a rational explanation and description of profit concepts on the basis of analysis of the available information.

\section{Edward and Bell's Concept of Profit}

Edgar O. Edwards and Philip W. Bell developed the wonderful concepts of profit (Edwards \& Bell, 1961).These are:

1. Realized profit;

2. Business profit; and

3. Accounting profit.

\subsection{Realized Profit}

According to Edwards and Bell, Realized profit is meant as inclusion of current operating profit and gains realized both through uses of assets and sales. It should be emphasized that any gains which are realized must first have been realizable gains (Porwal, 1961). These two profit components, realized gains and realizable gains, are therefore, not additive but rather are substitutes for each other.

$$
\text { Realized Profit }=\mathrm{A}+(\mathrm{C}+\mathrm{D})
$$

\section{Elements of Realized Profit}

There are three elements of Realized profit. These are as follows:

$\mathrm{A}=$ Current operating profit

$\mathrm{C}=$ Gains realized through use of assets

$\mathrm{D}=$ Gains realized through sales

A. Current operating profit

Current operating is the excess of selling price over current cost, realized cost savings represent the excess of current cost over historical cost for those inputs used in production and sales.

\section{$C=$ Gains realized through use of assets}

Gains realized which have occurred since the firm first purchased the asset. The gains are realized through the use of the assets in the firm's operations, they do not have their genesis in operating activities but rather in holding activities.

\section{$D=$ Gains realized through sales}

Gains realized through sales largely on materials that enter into the cost of goods sold and on those assets services whose value is estimated by depreciation charges. For most services purchased directly by the firm, such as the services of labor, the current cost and historic cost coincide and so the opportunity to realize a gain through use does not exists. In the case, however, where goods are purchased substantially in advance in their use (Glautier \& Underdown, 1994).

\subsubsection{Accounting Principles of Developing Realized Profit}

A logical first step toward improving the accounting concept of profit is the re-classification of gains realized through use as cost savings rather than as operating profit (Sinha, 2000). The resulting concept of profit can be called realized profit. It differs from accounting profit not in total but in its definition of components. Its measurement entails the application of the following principles:

1. In determining operating profit, inputs should be deducted from the current value of output at their current cost; and

2. The difference between the current cost and historic cost of inputs used in production of goods which are sold should be recorded as a realized cost saving.

\subsubsection{Realizable Profit}

Realizable Profit can be defined as the excess of the opportunity cost of the firm's total assets at the end of the production moment over the opportunity cost of the firm's total assets at the beginning of the production moment. Realizable profit is based on the measurement of opportunity costs and is the ideal profit concept for short-run purposes (Hendriksen, 1983).

\section{Realizable Profit $=$ Subjective profit + Reduction in subjective Goodwill.}

\section{Subjective Profit}

The subjective value of a firm represents a list of subjective events. it is the market value of a firm's assets, more particularly changes therein, that represents objective events (Parker \& Harcourt, 1969). Subjective profit is the target rate on the subjective value of the firm's assets at the beginning of the period and expected to accrue to a firm during a particular period is simply the expected increase in subjective value that would occur if no dividends were paid.

Subjective Goodwill

Subjective Goodwill is the excess of subjective value over market value, exists because the market does not share the expectations on which the firm is operating. 


\section{Expected Subjective Profit}

Expected subjective profit is the amount that could be paid out as dividends in any period without impairing subjective value.

$$
\text { Expected Subjective Pr ofit }=\left|\begin{array}{l}
\text { Expected } \\
\text { realizable } \\
\text { Pr ofit }
\end{array}\right|-\left|\begin{array}{l}
\text { Expected reduction } \\
\text { in subjective } \\
\text { Goodwill }
\end{array}\right|
$$

\section{Expected realizable Profit}

Expected realizable Profit is the size of the dividend a firm could plan to pay at the end of a period without impairing the market value of its assets (Jain \& Narang, 2000).

Exit Values: Exit values include the following values:

1. Expected values - values expected to be received in the future for output sold according to the firm's planned course of action.

2. Current values - values actually realized during the current period for goods or services sold.

3. Opportunity cost - values that could currently be realized if assets (without finished goods, semi finished goods, or raw materials) were sold (without further processing) outside the firm at the best prices immediately obtainable.

Entry Values: Entry values include the following values:

1. Present cost - the cost currently of acquiring the asset being valued.

2. Current cost - the cost currently of acquiring the inputs which the firm used to produce the asset being valued.

3. Historical cost - the cost at time of acquisition of the inputs which the firm in fact used to produce the asset being valued.

\subsubsection{The Realizable Profit Matrix}

To make the realizable profit clear we may use the Matrix $\&$ for that let us adopt the following letters as basic symbols:

A Assets

p Production moment

$\mathrm{h} \quad$ Holding intervals

b Beginning of the fiscal period

e End of the fiscal period

o Opportunity cost

The symbols $\mathrm{p}, \mathrm{h}, \mathrm{b}$, and $\mathrm{e}$ all have to do with the horizontal and vertical flow of assets through the fiscal period, and are used as prescripts or subscripts. When $\mathrm{p}$ or $\mathrm{h}$ is used as a prescript, it indicates inputs; when used as a subscript, it indicates outputs. Therefore we have the following:
${ }_{\mathrm{p}} \mathrm{A}$ Inputs of a production moment
$\mathrm{A}_{\mathrm{p}} \quad$ Outputs of a production moment
${ }_{\mathrm{h}} \mathrm{A} \quad$ Inputs of a holding interval
$\mathrm{A}_{\mathrm{h}} \quad$ Outputs of a holding interval

(As indicated above, $\mathrm{A}_{\mathrm{p}}={ }_{\mathrm{h}} \mathrm{A}$ at the end of any production moment and $A_{h}={ }_{p} A$ at the end of any holding interval.)

${ }_{\mathrm{b}} \mathrm{A}$ The firm's inherited inputs (its assets at the beginning of the fiscal period) which are assumed to enter immediately a production moment $\left({ }_{b} \mathrm{~A}\right.$ is therefore a particular ${ }_{\mathrm{p}} \mathrm{A}$ value)

$A_{e} \quad$ The firm's bequeathed inputs (its assets at the end of the fiscal period) ( $A_{e}$ is therefore a particular $A_{h}$ value)

Superscripts have to do with the method of valuing the assets. Thus, we have, for example,

${ }_{b} \mathrm{~A}^{0} \quad$ Opportunity cost of the firm's inherited inputs

Finally, we use the following symbols to denote profit concepts:

ROP Realizable operating profit

RCG Realizable capital gains

RP Realizable profit, the sum of ROP and RCG

The period begins with a list of the firm's assets valued at their opportunity cost on that date; it ends with a list of the firm's assets valued at the opportunity cost prevailing at the end of the period. The excess of the latter figure over the former represent the realizable profit earned by the firm during the particular fiscal period. Thus

$$
\mathrm{RP}=\mathrm{A}_{\mathrm{e}}{ }^{0}-{ }_{\mathrm{b}} \mathrm{A}^{0}
$$

Further the realizable operating profit for any particular production moments at time $(\mathrm{t})$ can be defined as

$$
\mathrm{ROP}_{(\mathrm{t})}=\mathrm{A}_{\mathrm{p}(\mathrm{t})}{ }^{0}-{ }_{\mathrm{p}} \mathrm{A}_{(\mathrm{t})}{ }^{0}
$$

And finally the capital gains according to the firm over any particular holding interval ending at time $(t)$ can be defined as

$$
\mathrm{RCG}_{(\mathrm{t})}=\mathrm{A}_{\mathrm{h}(\mathrm{t})}{ }^{0}-{ }_{\mathrm{h}} \mathrm{A}_{(\mathrm{t}-1)}{ }^{0}
$$

It follows that the total realizable operating profit earned by the firm over the specific fiscal period involving (n-t) production moments is given by

$$
\mathrm{ROP}=\sum_{0}^{\mathrm{n}-1} \mathrm{~A}_{\mathrm{P}^{0}}-\sum_{0}^{\mathrm{n}-1} \mathrm{P}^{0}
$$

This defined the total realizable operating profit of the firm as the excess of the total value of assets held at the end of all production moments over the total value of the assets introduced into all production moments. For reasons will become obvious it is desirable to restate equation (4) in such a way that the initial endowment of assets, which directly enter the first production moment, is separately stated. Let us therefore separate the second term in equation (4) into two parts, one of which will be the value of inherited inputs, ${ }_{b} \mathrm{~A}^{0}$, while the other will be the value of all intermediate inputs of the fiscal period. It should be noted that the term "intermediate" is used here with reference to the time period, not with reference to the stage of the production process. We can now rewrite equation (4) as follows:

$$
\mathrm{ROP}=\sum_{0}^{\mathrm{n}-1} \mathrm{~A}_{\mathrm{p}^{0}}-\sum_{1}^{\mathrm{n}-1} \mathrm{P} \mathrm{A}^{0}-{ }_{\mathrm{b}} \mathrm{A}^{0} .
$$


The total realizable capital gains which accrue to the firm over the entire fiscal period can be defined in similar fashion as the excess of asset values at the end of holding periods over the asset values at the beginning of holding periods where asset values in both cases are defined in terms of the opportunity costs prevailing at the moment of valuation. Thus we have by summing equation (3)

$$
\mathrm{RCG}=\sum_{1}^{\mathrm{n}-1} \mathrm{~A}_{\mathrm{h}^{0}}-\sum_{0}^{\mathrm{n}-1}{ }_{\mathrm{h}} \mathrm{A}^{0}
$$

It will be useful in this case to separate the first term of equation (6) into two elements, one of which will be the total value of the firm's assets at the end of the fiscal period. The remainder of the first term of equation (6) will be the output of all intermediate holding periods. Equation (6) becomes:

$$
\mathrm{RCG}=\mathrm{A}_{\mathrm{e}}{ }^{0}+\sum_{1}^{\mathrm{n}-1} \mathrm{~A}_{\mathrm{h}^{0}}-\sum_{0}^{\mathrm{n}-1} \mathrm{~h}^{0}
$$

We can now summarize the realizable profit concept, which is based on opportunity cost as a valuation technique, in the following matrix form:

The realizable Profit Matrix

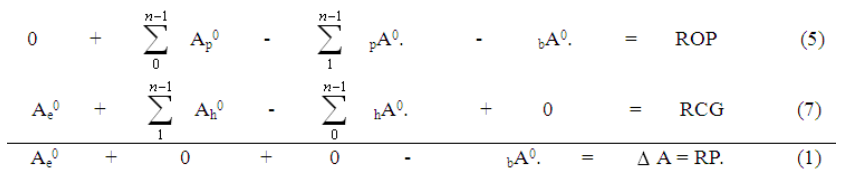

As the outputs of all production moments are equal to the inputs of all holding intervals, the vertical equation in the second column,

$$
\sum_{0}^{n-1} \mathrm{~A}_{\mathrm{p}}{ }^{0}-\sum_{0}^{n-1}{ }_{\mathrm{h}} \mathrm{A}^{0}
$$

must equal to zero. Furthermore, because the inputs of all intermediate holding periods are equal to the outputs of all intermediate holding periods, the vertical equation in the third column,

$$
\sum_{1}^{n-1} \mathrm{~A}_{\mathrm{h}}{ }^{0}-\sum_{1}^{n-1}{ }_{\mathrm{p}} \mathrm{A}^{0}
$$

must also equal to zero. The sum of the realizable profit equation and the realizable capital gains equation is therefore $\mathrm{A}_{\mathrm{e}}{ }^{0}-{ }_{\mathrm{b}} \mathrm{A}^{0}$.

\subsection{Business Profit}

According to Edwards and Bell, Business profit is defined to include current operating profit and realizable cost savings. The business profit is based upon the application of the realization criterion on a production basis and on the use of the realizable principle over time. Entry values are used as a basis for valuation of assets on hand, but these entry values carry current dates; all assets are carried at current cost but no gain from production is recognized until final sale. There are two dimension realization criterions: production dimension and a time dimension. These two dimensions to the realization criterion, of the profit concept are presented as below:

A Comparative Picture of Realization and Realizable criteria

\begin{tabular}{lll}
\hline $\begin{array}{l}\text { Historical and } \\
\text { Current values }\end{array}$ & $\begin{array}{l}\text { Entry values } \\
\text { (Realization } \\
\text { Principle) }\end{array}$ & $\begin{array}{l}\text { Entry values } \\
\text { (Realizable } \\
\text { Principle) }\end{array}$ \\
\hline $\begin{array}{l}\text { Historical values } \\
\text { (Realization Principle) }\end{array}$ & Accounting Profit & Historic values \\
$\begin{array}{l}\text { Current values } \\
\text { (Realizable Principle) }\end{array}$ & Business Profit & Realizable Profit \\
\hline
\end{tabular}

A business profit concept requires no knowledge of production while the realizable profit concept requires no knowledge of sales. Production itself generates no profit in the current cost approach because outputs are valued as the sum of the current cost of contained inputs. Profit arises when an exit value is substituted for an entry value (Jones, 1935). When a sale price is substituted for the current cost of the inputs sold. This change in the method of valuation lies at the heart of current operating profit, while realizable operating profit depends mainly on the change in the form of the assets being valued.

Edwards and Bell developed the concept of business profit. According to their view, business profit concept is based on replacement cost valuation and recognizes only the gains accruing during the period. More specifically, business profit comprises, (i) the current operating profit (X) which is the difference between the realized revenues and the corresponding replacement cost, current operating profits is defined as excess over a period of the current value of output sold over the current cost of the related inputs. (ii) the realized and accrued holding gains of the period (Y) and (iii) the unrealized holding gains and losses accruing in the period (W). A holding gain arises whenever the current market value of an asset exceeds its historical cost. Thus business profit (Bi) may be expressed as:

$$
\mathrm{Bi}=\mathrm{X}+\mathrm{Y}+\mathrm{W}
$$

Where-

$\mathrm{Bi}=$ Business profit

$\mathrm{X}=$ Current operating profit

$\mathrm{Y}=$ Realized and accrued holding gains of the period

$\mathrm{W}=$ Unrealized holding gain and losses accruing in the period.

\subsubsection{Components of Business Profit}

The possible components of business profit are: 1) current operating profit; 2) realizable cost savings; 3) realized capital gains; and 4) realized cost savings.

1) Current operating profit:

Current operating profit is the excess over a period of the current value of output sold over the current cost of 
the related inputs.

2) Realizable cost savings:

A realizable cost saving is the increase in the current cost of assets while held by the firm during the fiscal period.

3) Realized capital gains:

A realized capital gain is the excess of proceeds over historic costs on the irregular sale or disposal of assets.

4) Realized cost savings:

A realized cost saving is the excess of the current cost over the historic cost of inputs used in producing output sold.

These are not all independent components. In particular, (3) and (4) are alternatives to (2) as a way of measuring capital gains.

\subsubsection{The Business Profit Matrix}

Edwards and Bell developed the Business Profit with Profit Matrix. As operating profit is related to the sale of assets and not to their production, Edwards and Bell needs to deal only with sale moments and holding intervals. They assumes that the firm to start the period with an inheritance of assets valued at current cost, ${ }_{\mathrm{b}} \mathrm{A}^{\mathrm{c}}$, and to end the period with another set of assets valued also at current cost, $A_{e}{ }^{c}$. No dividend payments or capital contributions have occurred. Business profit, BP, can be defined as follows:

$$
\mathrm{BP}=\mathrm{A}_{\mathrm{e}}^{\mathrm{c}}-{ }_{\mathrm{b}} \mathrm{A}^{\mathrm{c}}
$$

$\mathrm{BP}=$ Business Profit.

$\mathrm{A}_{\mathrm{e}}^{\mathrm{c}}=$ Assets value at current cost of the beginning of the period.

${ }_{\mathrm{b}} \mathrm{A}^{\mathrm{c}}=$ Assets value at current cost at the end of the period.

The business profits are divided into current operating profit and realizable cost savings. The value of any sale moment of firm's assets (the inputs of the following interval) must include receipts from the sale of assets, $\mathrm{A}_{\mathrm{s}}{ }^{\mathrm{r}}$, plus the value of assets remaining unsold, $\mathrm{A}_{\mathrm{u}}{ }^{\mathrm{c}}$.

$$
{ }_{\mathrm{h}} \mathrm{A}_{(\mathrm{t})}{ }^{\mathrm{c}}=\mathrm{A}_{\mathrm{s}(\mathrm{t})}{ }^{\mathrm{r}}+\mathrm{A}_{\mathrm{u}(\mathrm{t})}{ }^{\mathrm{c}}
$$

${ }_{h} \mathrm{~A}_{(t)}{ }^{c}=$ At the end of total value of firm's assets.

$\mathrm{A}_{\mathrm{s}(\mathrm{t})}{ }^{\mathrm{r}}=$ The value receipts from the sale of assets.

$A_{u(t)}{ }^{c}=$ The value of assets remaining unsold.

The beginning of any sale moment, the total value of the firm's assets (those assets held at the end of the last holding interval) can be identified as realizable profit inputs destined for immediate sale, ${ }_{s} \mathrm{~A}^{\mathrm{c}}$, or as realizable operating profit inputs not to be sold, ${ }_{\mathrm{u}} \mathrm{A}^{\mathrm{c}}$.

$$
\mathrm{A}_{\mathrm{h}(\mathrm{t})}{ }^{\mathrm{c}}={ }_{\mathrm{s}} \mathrm{A}_{(\mathrm{t})}{ }^{\mathrm{c}}+{ }_{\mathrm{u}} \mathrm{A}_{(\mathrm{t})}{ }^{\mathrm{c}}
$$

When (3) is subtracted from (32) we have current operating profit for a particular sale moment.

$$
\begin{aligned}
\operatorname{COP}_{(t)} & ={ }_{h} A_{(t)}{ }^{c}+A_{h(t)^{c}} \\
& \left.=\left(A_{s(t)^{t}}-{ }_{s} A_{(t)}\right)+\left(A_{u(t)^{c}}{ }_{s} A_{(t)}\right)^{c}\right)
\end{aligned}
$$

But inputs of a sale moment which are not sold must be equal to the unsold outputs because unsold outputs are valued at the current cost of all the inputs contained therein. Thus equation (4) simplifies to

$$
\mathrm{COP}_{(\mathrm{t})}=\mathrm{A}_{\mathrm{s}(\mathrm{t})}{ }^{\mathrm{r}}-{ }_{\mathrm{s}} \mathrm{A}_{(\mathrm{t})}{ }^{\mathrm{c}}
$$

The current operating profit earned throughout the fiscal period can be defined, thus as follows:

$$
\mathrm{COP}=\sum_{0}^{n-1} \mathrm{~A}_{\mathrm{s}}^{\mathrm{r}}-\sum_{0}^{n-1}{ }_{\mathrm{s}} \mathrm{A}^{\mathrm{c}}
$$

Identifying those assets held at the beginning of the fiscal period which are immediately sold as ${ }_{\mathbf{b s}} \mathbf{A}^{\mathbf{c}}$, we have

$$
\mathrm{COP}=\sum_{0}^{n-1} \mathrm{~A}_{\mathrm{s}}^{\mathrm{r}}-\sum_{1}^{n-1}{ }_{\mathrm{s}} \mathrm{A}^{\mathrm{c}}-{ }_{\mathrm{bs}} \mathrm{A}^{\mathrm{c}}
$$

In order to keep account of unsold assets, let us sum the last term of equation (4) for all sale moments, identifying separately those initial assets not immediately sold as ${ }_{b u} \mathrm{~A}^{\mathrm{c}}$. We have

Profit on unsold assets $=\sum_{0}^{n-1} \mathrm{~A}_{\mathrm{u}}{ }^{\mathrm{c}}-\sum_{1}^{n-1}{ }_{\mathrm{u}} \mathrm{A}^{\mathrm{c}}-{ }_{\mathrm{bu}} \mathrm{A}^{\mathrm{c}}=0$

Realizable cost savings for a particular holding interval are simply the excess of the current cost of assets at the end of the interval over their current cost at the beginning, that is

$$
\operatorname{RSP}_{(\mathrm{t})}=\mathrm{A}_{\mathrm{h}(\mathrm{t})}{ }^{\mathrm{c}}-{ }_{\mathrm{h}} \mathrm{A}_{(\mathrm{t}-1)}{ }^{\mathrm{c}}
$$

Summing all holding intervals and segregating those assets held at the end of the fiscal period, $\mathrm{A}_{\mathrm{e}}{ }^{\mathrm{c}}$, yields

$$
\mathrm{RCS}=\mathrm{A}_{\mathrm{e}}^{\mathrm{c}}+\sum_{1}^{n-1} \mathrm{~A}_{\mathrm{h}}{ }^{\mathrm{c}}-\sum_{0}^{n-1}{ }_{\mathrm{h}} \mathrm{A}^{\mathrm{c}}
$$

Using the appropriate equations we can now define business profit and its components in matrix from as follows:

\section{The Business Profit Matrix}

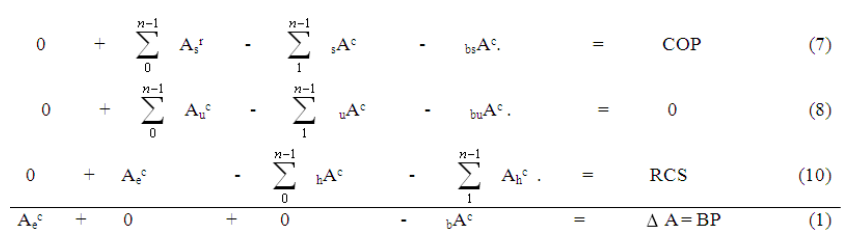

The first vertical equation adding to zero states that receipt from sales plus the value of unsold assets equals the total value of assets which enter holding intervals. The second vertical equation adding to zero states that assets held at the end of holding intervals are the inputs contained in assets sold and unsold. 


\subsubsection{Accounting Principles of Business Profit}

If business profit is to be determined, certain accounting principles are to be followed. As stated earlier, business profit is defined to include current operating profit and realizable cost savings its measurement requires data on the price changes of individual assets and entails the application of the following principles:

1. When price changes increases the value of assets, realizable cost savings should be recorded. These from the capital gains element of business profit. Similarly, when price changes decrease the value of an asset, realizable capital losses should be recorded (Gillman, 1939).

2. When an asset or asset service is used in production, its current cost should be deducted from the current value of output to determine operating profit (Cowley, 1974).

When these principles are applied in the accounts, the fundamental accounting equation is modified from historical cost basis to a current cost basis, resulting into business profit. Barring dividends and new contribution of capital by shareholders, the following relationship holds:
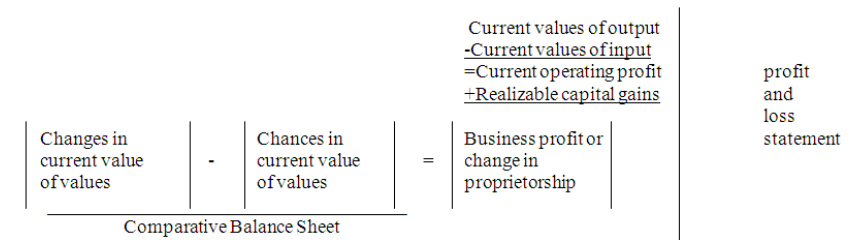

A third principle can be enunciated:

3. The difference between current cost and historical cost of assets or asset services used in production also marks the conversion of what was a realizable gain to realized gain. This amount should be transferred from the unrealized cost savings account to a realized cost savings account (Edey, 1970).

Principle (3) applied in the accounts in conjunction with principle (1) that yields data for realized profit.

\subsection{Accounting Profit}

Edwards and Bell basically developed business income. It would be beneficial to understand between accounting profit and business profit. Accounting profit is defined as the difference between the realized revenues arising from the transactions of the period and the corresponding historical costs. Realized holding gains and losses are included in the accounting profit. Realized holding gains and losses may be divided into two elements, first, the holding gains and losses realized and accrued during the period, second, the holding gains and losses realized during the period but accrued during previous periods. More specially, accounting profit (Ai) may be expressed as:

$$
\mathrm{Ai}=\mathrm{X}+\mathrm{Y}+\mathrm{Z}
$$

Where $\mathrm{Ai}=$ Accounting profit

$\mathrm{X}=$ Accounting operating profit

$\mathrm{Y}=$ Realized and accrued holding gains of the period

$\mathrm{Z}=$ Realized and accrued holding gains of the period accruing in previous period.

More clearly, the accounting profit has the following accounting relationships:

1) Sales (Current values) - Expenses (Historical costs) $=$ Accounting profit + Realized capital gains.

2) Change in assets (at historical costs) - Changes in liabilities (at historic costs) $=$ Accounting profit

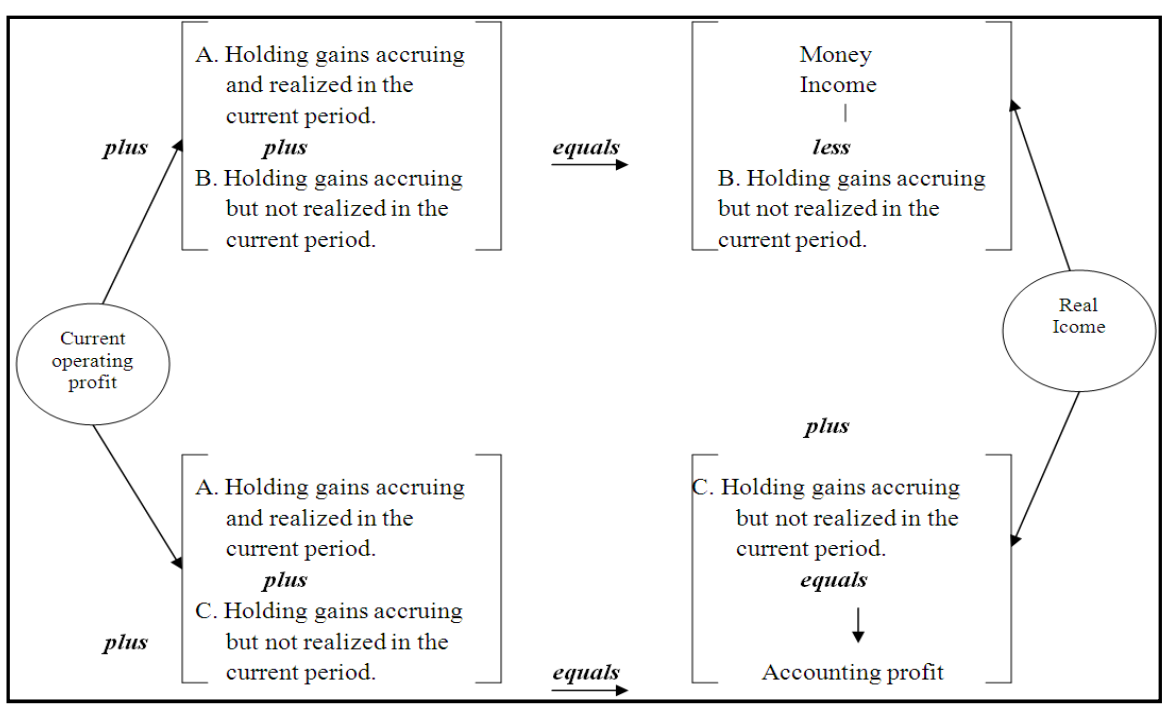

Source: R.H. Parker and G.C. Harcourt, eds., Readings in the Concept and Measurement of Income (New York: Cambridge university Press, 1969 , p 6

Figure 1. Relationship between Accounting profit and business profit

\subsubsection{Relationship between Accounting Profit and Edwards} \& Bell's Concept of Profit

Comparing accounting profit with business profit, it can be inferred that the business income is equal to the accounting profit less the realized holding gains of the period accruing in previous periods and plus the unrealized holding gains and losses. The relationship between business profit and accounting profit is shown in Figure 1. 
The difference between accounting profit and business profit is illustrated by the following example. Assume 2000 units are purchased at a price of Tk. 1 per unit. At P1 (period I) their replacement cost was Tk. 2 per unit. The 2000 units were sold at P2 (period II) f or Tk. 3 per unit when replacement cost was Tk. 2.50 per unit. The differences between the accounting profit and business profit are as follows:

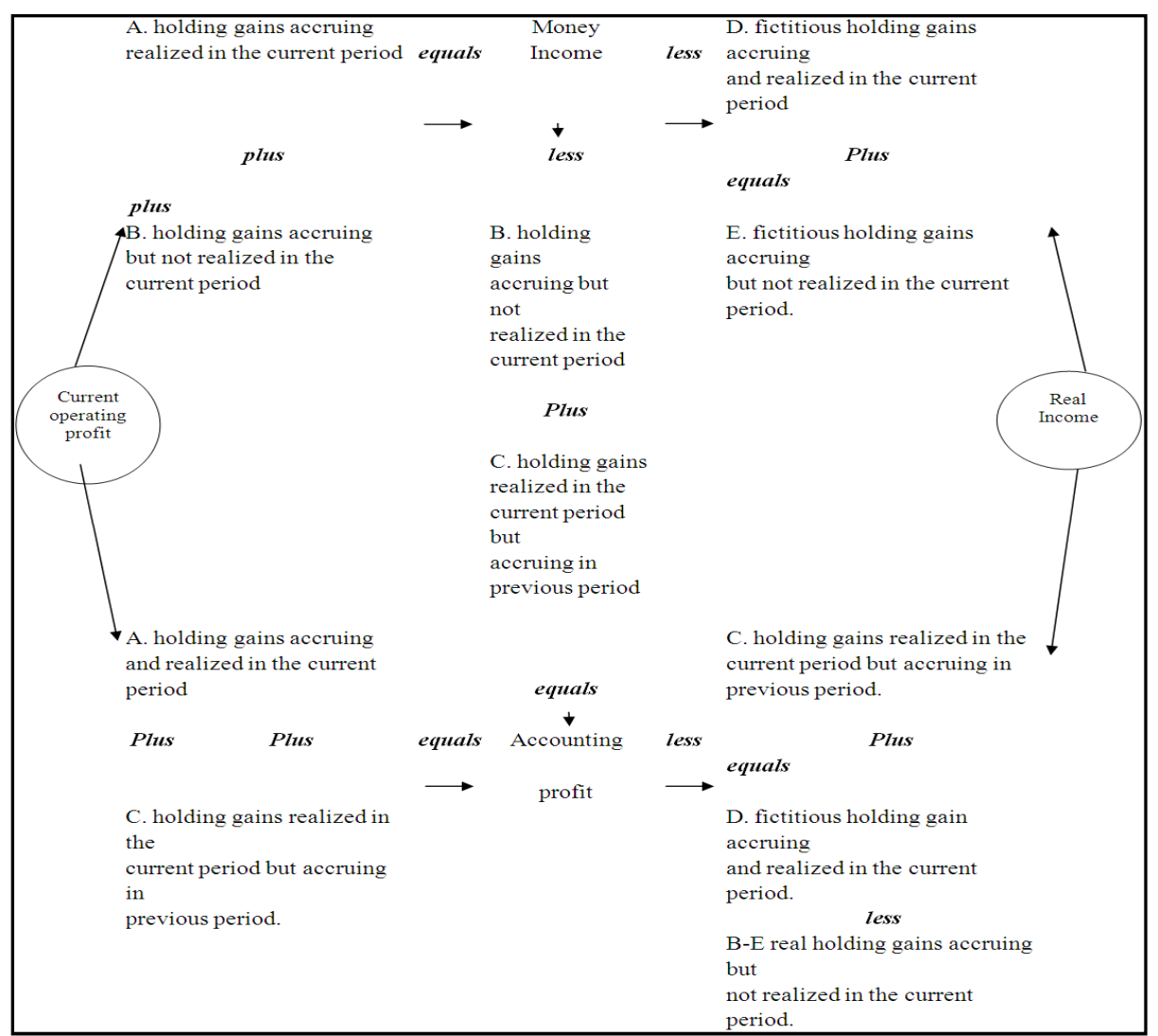

Source: R.H. Parker and G.C. Harcourt, Readings in the Concept and Measurement of Income (New York: Cambridge university Press, 1969, p.7

Figure 2. Relationship between Current operating profit and Rea income Relationship among Concepts of Measurable Profit

\begin{tabular}{|c|c|c|c|c|c|c|c|c|c|c|}
\hline \multirow{4}{*}{ Different Profits } & \multicolumn{7}{|l|}{ Inclusions } & \multicolumn{3}{|c|}{ Deviations from real business profit } \\
\hline & \multirow{3}{*}{$\begin{array}{l}\text { Current } \\
\text { operating } \\
\text { profit }\end{array}$} & \multirow{3}{*}{$\begin{array}{l}\text { Real gains } \\
\text { Realizable } \\
\text { (gains } \\
\text { arising in } \\
\text { this } \\
\text { period) }\end{array}$} & & & \multicolumn{3}{|c|}{ Fictional gains } & \multirow{3}{*}{$\begin{array}{l}\text { Excludes } \\
\text { accrued } \\
\text { but } \\
\text { unrealized } \\
\text { real gains }\end{array}$} & \multirow{3}{*}{$\begin{array}{l}\text { Includ } \\
\text { es } \\
\text { fiction } \\
\text { al } \\
\text { gains }\end{array}$} & \multirow{3}{*}{$\begin{array}{l}\text { Confuses } \\
\text { gains realized } \\
\text { through use } \\
\text { with operating } \\
\text { profit }\end{array}$} \\
\hline & & & \multicolumn{2}{|c|}{ Realized by } & \multirow{2}{*}{$\begin{array}{l}\text { Realizable } \\
\text { (gains } \\
\text { arising in } \\
\text { this period) }\end{array}$} & \multicolumn{2}{|c|}{ Realized by } & & & \\
\hline & & & Use & Sale & & Use & Sale & & & \\
\hline 1. Accounting profit & $\mathrm{O}$ & & $\mathrm{O}$ & $\mathrm{C}$ & & $\mathrm{O}$ & $\mathrm{C}$ & $\mathrm{X}$ & $\mathrm{X}$ & $\mathrm{X}$ \\
\hline 2. Real Accounting profit & $\mathrm{O}$ & & $\mathrm{O}$ & $\mathrm{C}$ & & & & $\mathrm{X}$ & & $\mathrm{X}$ \\
\hline 3. Realized profit & $\mathrm{O}$ & & $\mathrm{C}$ & $\mathrm{C}$ & & $\mathrm{C}$ & $\mathrm{C}$ & $\mathrm{X}$ & $\mathrm{X}$ & \\
\hline 4. Real realized profit & $\mathrm{O}$ & & $\mathrm{C}$ & $\mathrm{C}$ & & & & $\mathrm{X}$ & & \\
\hline 5. Business profit & $\mathrm{O}$ & $\mathrm{C}$ & & & $\mathrm{C}$ & & & & $\mathrm{X}$ & \\
\hline 6. Real business profit & $\mathrm{O}$ & $\mathrm{C}$ & & & & & & & & \\
\hline
\end{tabular}

$\mathrm{O}=$ Included as operating profit, $\mathrm{C}=$ Included as capital gains (and losses) or cost savings.

Source: Edward, E.O. \& Bell, P.W. "The Theory and measurement of business income" (University of California Press, Berkeley, Loss Angels, London.) $7^{\text {th }}$ edition, 1961. p130

Neither business profit nor accounting profit makes any allowance for changes in the general price level, both real gains resulting from changes in relative prices and fictitious gains resulting from the effects of a rise in the general price level being regarded as profit. This vital question has led to the emergence of real profit concept. For a business enterprise, real income can be obtained by separating holding gains into their real and fictitious elements. Figure 2 shows 
the relationship between current operating profit, accounting profit, business profit and real profit.

\subsubsection{Principles of Relationship}

Five principles setting forth the relationships among the profit concepts can now be enumerated:

1. All concepts of operating profit are identical if purchase prices are constant (Hicks, 1946);

2. Realized profit equals FIFO profit at all times;

3. LIFO operating profit and current operating profit are less than FIFO operating profit when purchase prices are rising and greater than FIFO operating profit when purchase prices are falling (Walton, 1977);

4. Only the amounts of business profit before taxes, and its components, are always identical for different periods containing the same events (Connor \& Moira, 1976);

5. If increments in inventories are priced under LIFO at early purchase prices, in any period in which physical inventory has increased, LIFO operating profit is slightly less than current operating profit if purchase prices are rising, and slightly greater than current operating profit if purchase prices are falling; if physical inventory has decreased, either may be the larger. If increments are priced in at average purchase prices, the two concepts will be equivalent; if priced in at late purchase prices, LIFO profit will slightly exceed COP (Perrin, 1976).

\section{Weaknesses of the Concept of the Profit}

According to my observation, Edwards \& Bell's concept of profit has some weaknesses. These are:

1. Edwards \& Bell called economic income as 'subjective income' and observed that it cannot be satisfactorily applied in practice by business enterprises. The notion of "well offense" is indeed a matter of individuals" personal preferences. Because of the aforesaid limitations, the concept of economic income has little application to the area of financial accounting and reporting;

2. Economic concept of income has no agreement as to the meaning of "better offense" that occurs in specific time periods. Also, this term is not well defined in case of business enterprises. The great weakness lies in measuring the net assets at the beginning and at the end of the period, which are required to ascertain income. There are several methods of valuation of assets. In certainly, the cash flows and benefits could be determined with accuracy. But certainly is a rare factor, and the expected future cash flows upon which income extant and exposit depends, are subjective to a great deal of uncertainty. In practice, the economic income would be subjective to extreme and inaccuracies of the predictions;
3. In determining accounting profit, it is the historical cost of inputs that is deducted from the current value of output sold and record of current cost is kept. Therefore, the operating profit that is consistent with accounting principles includes in addition to current operating profit and realized cost savings. In accounting operating profit no distinction is drawn between these two elements;

4. Assets are carried at depreciated historical cost on the traditional balance sheet. Hence, no gains are recorded as they arise from realizable cost savings excluded from accounting profit;

5. The excess of the proceeds from the irregular or extraordinary sale of assets over their depreciated historical costs is recorded as a capital gain, it is only these gains realized through irregular sale (realized capital gains) that are counted as capital gains in accounting profit;

6. Capital gains are counted only when realized. This means some of the events of past periods, notably price changes and the gains or losses associated with them, are treated as though they were events of the current period;

7. The recording of gains when realized permits past events to cloud current events. The evaluation of managerial expectations cannot proceed satisfactorily if events over the whole life of an asset are compared with those events expected to occur in only the current period;

8. Gains realized are confused with operating profit. The profit which arises from holding assets is counted in production;

9. Individual price changes of assets held by the firm are not recorded as they occur. Instead, gains are credited to the period in which they are realized; as a result balance sheet values are based on historical cost, meaningful current costs being excluded;

10. Changes in the price level introduced two difficulties found into the measurement and interpretation of accounting data. These are business profit measures the increases over a period in the firm's command over money values. This increase does not represent an equal change in the firm's current real investment unless the price level has been constant over the period. Maintaining the money value of a firm's assets when the price level is rising represents a decrease in the purchasing power controlled by the firm; and

11. All of the concepts of profit Edwards and Bell have discussed would be identical under so called stationary state conditions. When population, tastes, resources, and technology are given, it is reasonable to expect all prices to be constant. Capital gains disappear, price level changes vanish, and the most plaguing problems of measurement in a dynamic economy are dissipated. 


\section{Conclusions}

According to Edwards and Bell in determining operating profit inputs should be deducted from the current value of output at their current cost would result in an understatement of total profit when input prices were rising and an overstatement when input prices were falling because gains and losses realized through use would go unrecorded. If the LIFO technique are used for costing inventories and the cost of goods sold, certain inputs are usually deducted from sales at current cost but no record is kept of the gain or loss arising because current cost differs from historical cost. Realized gains are false one because the total current cost must be recovered from sales if the replacement of the physical inputs is being possible. The existence of the gain is confused with the disposition of the gain. The gain exists and has been realized. The firm can dispose of the gain by paying dividends, by purchasing another kind of merchandise, by buying securities, or in other ways. All assets (and liabilities) held at the beginning of the fiscal period must be valued at the opportunity costs of those assets (and liabilities) on that date. The gains resulting from all prior production moments and holding intervals (less dividends plus new contribution of profit) are included in the net assets shown on balance sheet. The values represent the amount which the firm is risking in the succeeding fiscal period. The values recorded at the end of the fiscal period will reflect the opportunity costs prevailing at that time. If the price level has been constant, these two balance sheets can be directly compared. The change in net asset value which has occurred over the period is a measure of the total realizable profit which has been earned by the firm during the period under consideration. In defining operating profit, it is the opportunity cost of assets at the beginning of a production moment which is subtracted from the opportunity cost of assets at the end of the production moment. The amount of capital gain is determined by subtracting the opportunity cost of the assets at the beginning of the holding interval from the opportunity cost of the same assets at the end of the holding interval. The opportunity cost basis for record-keeping has this unique characteristic: except for the initial acquisition of output, all gains and losses can be attributed either to changes in form or to changes in date and none can be attributed to changes in the method of valuation itself. The business profit requires no knowledge of production while the realizable profit requires no knowledge of sales. Profit itself generates no profit in the current cost approach because outputs are valued as the sum of the current costs of contained inputs. Business profit arises when an exit value is substituted for an entry value, when a sale price is substituted for the current cost of the inputs sold. The realizable capital gains which are a part of total realizable profit and the realizable cost savings which are a part of business profit.

\section{References}

[1] Connor \& Moira, (1976). "Developments in Methods of Estimating Manufacturers' Stock Changes", CSO-Economic Trends.

[2] Cowley, A. H., (1974). "Accounting for Inflation", Central Statistical Office-Economic Trends, August.

[3] Edwards, Edgar O. and Bell, Philip W., (1961). The Theory and measurement of business income. University of California Press, Berkeley, Los Angeles, London. $7^{\text {th }}$ edition.

[4] Edey, H. C.,(1970). "The Nature of Profit", Accounting and Business Research, winter.

[5] Glautier M. W. E. and Underdown, B., (1994). Accounting Theory and Practice, Pitman, Fourth Edition.

[6] Gilman, S. (1939). Accounting Concepts of Profit, New York: The Rolland Press Co.

[7] Hendriksen, Eldon S. (1983). Accounting Theory, Richard D. Irwin, Fourth Edition.

[8] Hicks, J. R.,(1946). Value and Capital, second edition, page 170.

[9] Jain,S.P. \& Narang, K.L., (2000). Advanced Accountancy, Kalyani Publishers, $10^{\text {th }}$ Edition.

[10] Jones, R.C. (1935). "Financial Statements and the Uncertain Dollar", The Journal of Accountancy 40, 171-197.

[11] Porwal, L. S. ,(1994). Accounting Theory, an Introduction, Tata Macgraw Hill Publishing Company Limited, New Delhi, Third Edition,

[12] Parker R. H. and Harcourt, G.C. (1969). Reading in the concept and Measurement of Income, Cambridge University Press, New York.

[13] Perrin, J. R., (1976)."Inflation Accounting is not Economic Valuation", Editorial to Journal of Business Finance and Accounting.

[14] Sinha, Gokol (2000). Accounting Theory and Management Accountancy, Book World, 61 Sitaram Ghosh Street, Kolkata $700001,9^{\text {th }}$ Edition, 2000.

[15] Walton, John, (1977). "Current Cost Accounting and the Concept of Corporate Income", The Business Economist, Volume 9, No. 1, Summer 1977, Society of Business Economists. 